\title{
Ratlarda Yaşlanmanın Mesane Fonksiyonları Üzerinde Oluşturduğu Değişikliklerin İncelenmesi
}

\author{
Evaluation of Alterations in Bladder Functions Associated With Aging in Rats
}

\author{
Osman Akyüz', Kamil Çam², Özge Uzun ${ }^{3}$ \\ 1 Medicine Hospital Üroloji Anabilim Dalı, İstanbul, Türkiye \\ 2 Marmara Üniversitesi Tıp Fakültesi Üroloji Anabilim Dalı, İstanbul, Türkiye \\ 3 Okan Üniversitesi Tıp Fakültesi Farmakoloji Anabilim Dalı, İstanbul, Türkiye
}

Geliş tarihi (Submitted): 03.06.2019 Kabul tarihi (Accepted): 25.10 .2019
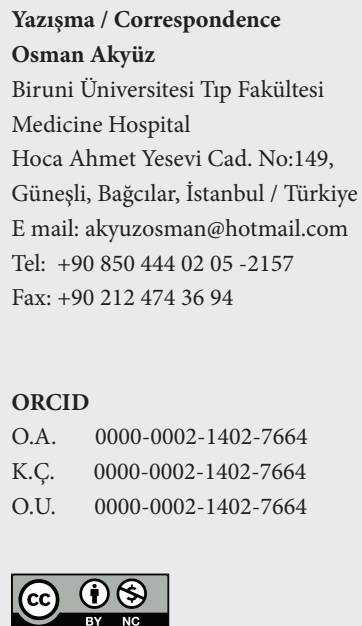

Bu eser Creative Commons AttfGayriticari 4.0 Uluslararassı Lisansı ile lisanslanmıștır.

\section{Özet}

Amaç: Alt üriner sistem semptomları (AÜSS) sadece iyi huylu prostat hiperplazisine (BPH) bağlı olmayıp, mesanede yapısal veya fonksiyonel değişikliklere neden olabilecek herhangi bir durum ile ilişkili olabilir. Bununla birlikte, AÜSS’lere yol açan kesin mekanizmalar henüz net bir şekilde tanımlanmamıştır. Bu deneysel çalışmada yaşlanmanın organ banyosu ortamında mesane fonksiyonları üzerinde oluşturduğu değişikliklerin incelenmesi amaçlandı.

Gereç ve Yöntemler: Çalışmada kullanılan Wistar cinsi sıçanlar 10 adet yaşlı (24 aylık) ve 10 adet genç (6 aylık) olmak üzere iki gruba ayrıldı. Detrüsör şeritleri, içerisinde Krebs- Heinseleit çözeltisi bulunan organ banyosuna asıldı. Kontraksiyon için asetilkolin ve $\mathrm{KCl}$ kullanılırken, aynı ajanların L-NAME (N $\omega$-Nitro-L-argininemethylester) varlığında verdikleri yanıtlar ölçüldü. Gevşeme için asetilkolin ve $\mathrm{KCl}$ ile kasılmış dokularda fenilefrin ve sodyum nitroprussid yanıtları ölçüldü. Elde edilen veriler student's t testi kullanılarak istatistiksel olarak karşılaştırıldı.

Bulgular: Genç ve yaşlı sıçan detrusörünün kasılma yanıtları karşılaştırıldığında, asetilkolinin yüksek konsantrasyonlarında gençlerde kasılma gücü yaşlı gruba göre belirgin yüksek bulundu. Yine L-NAME varlığında asetilkoline alınan yanıt aynı şekilde anlamlı olarak yüksek bulunurken, her iki grup arasında $\mathrm{KCl}$ ve L-NAME varlığında KCl'ye alınan yanıtlarda anlamlı farklılık saptanmadı. Gevşeme yanıtlarına bakıldığında ise asetilkolinle kasılmış yaşlı sıçan mesanelerinin, gençlere göre fenilefrine ve sodyum nitroprusside düşük dozlarda anlamlı gevşeme yanıtı verdiği görüldü. $\mathrm{KCl}$ ile kasılmış dokularda ise yaşlı sıçanların sodyum nitroprussid için düşük, fenilefrin için ise yüksek konsantrasyonlarda anlamlı gevşeme yanıtı gösterdiği görüldü.
Abstract

Objective: It is clearly know that lower urinary tract symptoms (LUTS) are not solely associated with benign prostatic hyperplasia. Any process that can cause structural or functional changes in the bladder might also be related with the development of LUTS. Nevertheless, the exact mechanisms causing LUTS have not clearly been defined yet. The aim of this experimental study was to investigate the impact of aging on detrusor functions using organ bath

Material and Methods: Rats were divided into two groups as young and old. The first group consited of 10 rats with 6 monts of age, while the second group contained 10 rats with 24 months of age. The isolated detrusor strips were placed in the organ bath containing Krebs -Heinseleit solution. Ach (Acetylcholine) and $\mathrm{KCl}$ were utilized to study contraction. The response to same agents were obtained with the addition of L-NAME ( $\mathrm{N} \omega$-Nitro-L-arginine methyl ester). Relaxation function was compared between these groups by using phenilefrine and SNP (Sodium nitropruccide). Student's t test was used to assess the statistical significance.

Results: The contraction response to Ach with high concentrations was significantly powerful in young rats with compare to old rats. A similar significant response was observed in young rats when L-NAME was added to Ach. However, no significant difference was seen when $\mathrm{KCl}$ was applied. On the other hand, the old rats showed a significant relaxation response when low concentrations of phenilefrine and SNP were utilized in muscles that had been concracted by Ach. Moreover, when the muscles had been concracted by $\mathrm{KCl}$, a significantly higher relaxation was noticed by using low concentrations of SNP and high concentrations of phenilefrine in old rats with compare to young rats. 
Sonuç: Organ banyosu kullanılarak yapılan bu deneysel çalışmada, genç ve yaşlı rat mesanelerinde kontraktil ve gevşetici özellikte aynı ajanlara karşı farklı yanıtların alınması, yaşlanmayla mesanenin reseptör karakteristiklerinde değişiklik oluştuğunu düşündürmektedir. Dolayısıyla bu gözlem, yaşlanmanın mesane fonksiyonlarını etkileyerek AÜSS’ye neden olabileceği görüşünü desteklemektedir.

Anahtar Kelimeler: Yaşlanma, mesane, rat, organ banyosu
Couclusion: In this experimental study of aging bladder, a remarkable difference in bladder functions was observed between young and old rats in terms of responding various agents by using organ bath. This finding suggets a possible alteration in receptor properties of the bladder aging. Therefore, it can be postulated that aging may cause alterations in bladder functions which in turn may be associated with development of LUTS.

Keywords: Aging, bladder, rat, organ bath

\section{Giriș}

Alt üriner sistem semptomlarının (AÜSS) son derece önemli bir halk sağllğı sorunu olduğu ve 50 yaşüzeri her dört erkeğin birinde orta veya şiddetli derecede görüldügü bilinmektedir1. Yaşla birlikte bu oranın arttığı, özellikle batı toplumlarında beklenen yaşam süresinin uzaması nedeniyle yakın gelecekte bu oranın çok daha yüksek olacağ düşünülmektedir². Her ne kadar benign prostat hiperplazisine (BPH) bağlı mesane çıkım obstrüksiyonu AÜSS’nin en sık sebebi olarak kabul edilse de, patofizyolojisi henüz net olarak ortaya konmamıştır. Birçok epidemiyolojik çalışmada AÜSS ve BPH’nın progressif bir hastalık olduğu, her 10 yıllık yaş grubunda semptom skorunun iki puan arttığ 1 gösterilmiştir³. Yapılan araştırmalarda AÜSS olan hastaların üçte birinde obstrüksiyon saptanamaması nedeniyle, yaşlı erkeklerde görülen AÜSS’nin sadece mesane ç1kım obstrüksiyonuna bağlanamayacağı gösterilmiştir4 $\mathrm{Bu}$ durum obstrüksiyonu olan yaşlı erkeklerde medikal veya cerrahi tedavi ile semptomların neden tam olarak düzelmediğini de açıklamaktadır ${ }^{5}$. Yaşlanma ile birlikte her iki cinste de ürodinamik parametrelerde bozulma, rezidüel idrar miktarında artma, idrar akım hızında ve mesane kapasitesinde azalma olduğu ortaya konulmuştur ${ }^{6}$. AÜSS semptomlarının ortaya çıkmasında iskeminin rolü olabileceği de gösterilmiştir ${ }^{7}$ Hatta iskeminin erektil disfonksiyon ve AÜSS ilişkisini de açıklayabileceği belirtilmiştir. Yaşlanma ve iskemi birlikteliği de açıktır. Dolayısıyla yaşlanma mesane fonksiyonlarını obstrüksiyondan bağımsız da etkileyebilir.

Mesanenin kasılma fonksiyonları esas olarak adrenerjik, kolinerjik ve nonadrenerjik ve non-kolinerjik (NANC) mekanizmalar tarafından sağlanmaktadır. Normalde mesane düz kas hücreleri, kolinerjik muskarinik reseptör agonistleri ve intrensek kolinerjik sinirlerin elektriksel uyarımı ile kasılırlar. Mesanede moleküler klonlamaya göre beş adet, farmakolojik olarak ise 4 adet muskarinik reseptör (M) tanımlanmış olup $^{8}$ M1, M2 ve M3'ün mesanede yoğun bir şekilde bulunduğu gösterilmiştir 9 . Harris ve arkadaşları M3 reseptörlerinin asetilkolin ile uyarımının inositoltrifosfat hidrolizini, hücre kalsiyumun serbest kalmasını ve düz kas kasılmasını sağladığını göstermişlerdir. M3 reseptörlerinin asetilkolin ile uyarımı, inositoltrifosfat hidrolizine yol açarak hücre içi kalsiyum seviyesini artırır ve detrüsör kasında kasılmaya neden olur. M2 reseptörlerinin uyarılmasıyla da detrüsör kasılması oluşur. Ancak bu kasılma, $\beta$-adrenoreseptörlerin uyarılmasıyla gerçekleșen cAMP aracılı gevşemenin inhibisyonu ile dolayl yoldan olmaktadır ${ }^{10}$. Adrenerjik mekanizmalara bakıldığında ise beta $(\beta) 3$ reseptörlerin mesanede yoğun bir biçimde bulunduğu ve gevşemede rol oynadığı gösterilmiştir. $\beta 3$ reseptörlerin uyarılması ile adenilat siklazın aktive olması, cAMP'yi artırarak protein kirazı aktive eder ve detrüsör kasında gevşeme sağlanır ${ }^{11}$. Alfa $(\alpha)$ adrenerjik reseptörler ise normal mesane fonksiyonunda fazla önem taşımazlar. Ancak Lepor ve arkadaşları yaptıkları bir çalışmada instabil mesanelerde alfa adrenoreseptör yoğunluğunun arttığını göstermişlerdir ${ }^{12}$. Antikolinerjik ajanlarla detrüsör kasılmalarının tam olarak engellenememesi non-adrenejiknonkolinerjik (NANC) reseptörlerin varlığını düşündürmüştür. NANC reseptörlerin ATP (adenozintri fosfat) ile uyarılabilenleri purinerjik olarak adlandırılmıştır ${ }^{13}$. ATP salınımı mekanik gerilmeve elektriksel uyarıyla olur ve detrüsör kasılmasının ve miksiyonun başlatılmasında önemli rol oynar. Koliner jik sistem ise kasılmanın ve miksiyonun sürdürülmesini sağlar ${ }^{14}$. NANC reseptörlerin uyarılmasında rol oynayan bir diğer nörotransmitter nitrik oksit (NO) olup, 
idrar boşaltımı esnasında üretral düz kasların gevşemesini sağlayan ana inhibitör olarak tanımlanmıştır ${ }^{15}$. Mesanenin dolmaya başlaması ile birlikte oluşan mekanik sinyaller, duyu nöronlarında CB2 (Cannabinoid receptors) reseptörlerinin ve TRP kanallarının (transient receptor potential channels) aktivasyonuna yol açar. $\mathrm{Bu}$, nitrik oksit salınımına yol açarak sonunda detrusör, prostat ve üretrada düz kaslarında gevşeme sağlar ${ }^{16}$.

Literatürde yaşlı sıçan mesanelerinde asetilkoline alınan kontraksiyon yanıtını araştıran çalışmalar olmakla birlikte, asetilkolinle eş zamanlı nitrik oksit sentaz (NOS) inhibitörü olan L-NAME'in de kullanıldığ çalışmaya rastlanılmamıştır.

$\mathrm{Bu}$ deneysel çalışmada organ banyosu kullanılarak genç ve yaşlı sıçan mesane dokularının hem sadece asetilkoline ve KCl'ye hem de L-NAME varlığında asetilkolin ve KCl'ye verdikleri kasılma yanıtları incelenmiştir. Ayrıca asetilkoin ve $\mathrm{KCl}$ ile kasılmış mesane dokularının sodyum nitoprussid ve fenilefrine verdiği gevşeme yanıtları da ölçülmüştür. Yaşlanmanın mesane fonksiyonları üzerindeki etkileri in vitro ortamda incelenerek, AÜSS'deki olası rolünün araştırılması amaçland1.

\section{GEREÇ VE YÖNTEMLER}

$\mathrm{Bu}$ çalışma "Abant İzzet Baysal Üniversitesi Tip Fakültesi Deney Hayvanları Etik Kurulu” tarafından onaylandıktan sonra hayvan laboratuvarındaki sağlıklı erkek Wistar cinsi albino sıçanlar kullanılarak yapıldı. Sıçanlar 10 adet yaşlı ve 10 adet genç olmak üzere iki gruba ayrıldı. Yaşlı olanlar 24 aylık, ortalama 390 gram (gr) $(360$ - 430), genç olanlar ise 6 aylık ve ortalama 200 gr (180-220) ağırlığındaydı. Hayvanlara önce hafif eter inhalasyon anestezisi uygulandıktan sonra, standart intraperitoneal anestezi (ketamin $100 \mathrm{mg} / \mathrm{kg}$ ve ksilazin $1 \mathrm{mg} / \mathrm{kg}$ ) yapıldı. Anestezi sonrası orta hat insizyon ile mesaneye ulaşıldi. Mesaneden 2x2x10 mm boyutlarında doku şeritleri alınarak $+4 \mathrm{oC}$ derecede muhafaza edilen Krebs-Heinseleit fizyolojik çözeltisinin içine konuldu. Ardından sıçanlara dekapitasyon yöntemi ile ötenazi işlemi yapıldı.

Alınan doku şeritleri farmakoloji laboratuvarında içerisinde karbojen (\%95 O2 + \%5 CO2) ile gazlandırılmış Krebs-Heinseleit solüsyonu (NaCL:118 mM (mili- mol), KCL:4.7 mM, CaCI2 2.5 mM, MgSO47H2O:1.2 $\mathrm{mM}, \mathrm{NaHCO} 3: 2.5 \mathrm{mM}$ ve glukoz:11.1 mM, pH:7.4, 37 oC) bulunan 10 mililitre'lik (ml)izole organ banyosuna bir ucu sabit diğer ucu transdüsere bağlanarak asıldı. 1 gram (gr) gerilim uygulanarak 60 dakika (dk) dengeleme için beklendi ve bu süre boyunca $20 \mathrm{dk}$ 'da bir organ banyosunun solüsyonu değiştirlerek yenilendi.

\section{Organ Banyosu}

Deneylerde $10 \mathrm{ml}$ organ banyosundan oluşmuş bir düzenek kullanıldı. Gerilim kuvvetleri 0 ve 50 aralığında ölçüm yapabilen 0.01 gr duyarlılıkta olan transdüserler (MAY FDT 10-A Ankara, Türkiye) ile ölçüldü. Elde edilen değerler Biopac (MP30B-CE 10B 628 Santa Barbara - California - USA) sistemi ile kaydedildi.

\section{İzometrik Görünümün Sağlanması}

Mesane şeritleri 4/0 ipekle gerilim uygulanmadan cam organ banyosunda bir ucu sabit kancaya, diğer ucu transdüsere bağlanarak asıldı. Daha sonra hassas mikrovida sistemi ile birer gr gerilim uygulandı. Ardından $30 \mathrm{mM}$ KCL ile dokuların kasılabilirliği test edildi. Uygulanan KCL konsantrasyonuna ard arda benzer yanıtlar alındığ görüldükten sonra deneylere başlandı. Çalışmada kullanılan asetilkolin, $\mathrm{KCl}$, fenilefrin, $\mathrm{N} \omega$-Nitro-L-argininemethyl ester (L-NAME) ve sodyum nitroprussid Sigma (Sigma Chemical Company, USA)'dan sağlandı. Bu maddeler distile suda çözüldükten sonra Krebs-Heinseleit çözeltisinde seyreltildi.

\section{Kontraksiyon Çalışması}

Organ banyosundaki dokulara artan seviyelerde yanit elde etmek amaciyla, sirasiyla 10-9 M - 10-2 M arasında asetilkolin ve $10-90 \mathrm{M} \mathrm{doz}$ aralığında $\mathrm{KCl}$ konularak doz yanıt eğrileri elde edildi. Doz yanıt eğrilerinden FP60 programı kullanılarak EC50 değerleri hesaplandı. Ardından mesane şeritlerinin bulunduğu organ banyosuna 10-4 ML-NAME eklenerek 30 $\mathrm{dk}$ bekletildi. Bu süre sonunda yine artan kosantrasyonlarda asetilkolin ve $\mathrm{KCl}$ eklenerek alınan kasilma yanıtları kaydedilerek EC50 değerleri hesaplandı.

\section{Gevşeme Çalışması}

Asetilkolin submaksimal dozuyla (10-4 M) kontraksiyon platosu elde edildikten sonra mesane şeritlerinin bulunduğu havuzcuklara artan konsantrasyonlara 
göre gevşemem yanitları ölçülmek üzere 10-9 M - 10-3 M konsantrasyonları arasında fenilefrin eklenerek gevşeme yanıtları kaydedildi. Deney aynı konsantrasyon aralığında sodyum nitroprussid için de yapılarak gevşeme yanıtları ölçüldü. KCl'nin submaksimal dozu ile $(30 \mathrm{mM})$ kontrakte edilen dokularda da yukarıda belirtilen konsantrasyonlarda fenilefrin ve sodyum nitoprussid kullanılarak oluşan gevşeme yanıtları değerlendirildi. Gevşeme yanıtları elde edilen $\mathrm{KCl}$ kontraksiyonuna göre \% gevşeme olarak ifade edildi ve IC50 değerleri FP60 programı kullanılarak hesaplandı.

\section{İstatiktiksel Analiz}

Saptanan gerim değişiklikleri gr olarak değerlendirildi. Elde edilen veriler aritmetik ortalama $+/$ - ve aritmetik ortalamanın standart hatası (SEM) olarak değerlendirildikten sonra student's t testi kullanılarak karşılaştırıldı. $\mathrm{P}<0.05$ istatistiksel olarak anlamlı kabul edildi.

\section{BULGULAR}

\section{Kontraksiyon Çalışması}

Asetilkolinle yapılan kontraksiyon çalışmasında, 6 aylık sıçanlarda 24 aylıklara göre $10-4 \mathrm{M}$ ve daha yüksek dozlarda istatistiksel olarak anlamlı derecede yüksek kasılma yanıtı izlendi $(\mathrm{p}<0.05)$ (Şekil 1). Daha düşük dozlarda ise her iki grup arasında farkl1lik saptanmadı. 10-4 M L-NAME ile yarım saat preinkübasyon yapılan genç ve yaşlı sıçan mesane dokuları arasında, düşük dozlarda asetilkoline karşı alınan kasılma yanıtları arasında farklılık saptanmadı. 10-5 M ve daha yüksek dozlarda ise genç sıçanların verdiği kasılma yanıtında istatistiksel olarak anlamlı artış izlendi $(\mathrm{p}<0.05)($ Şekil 2).

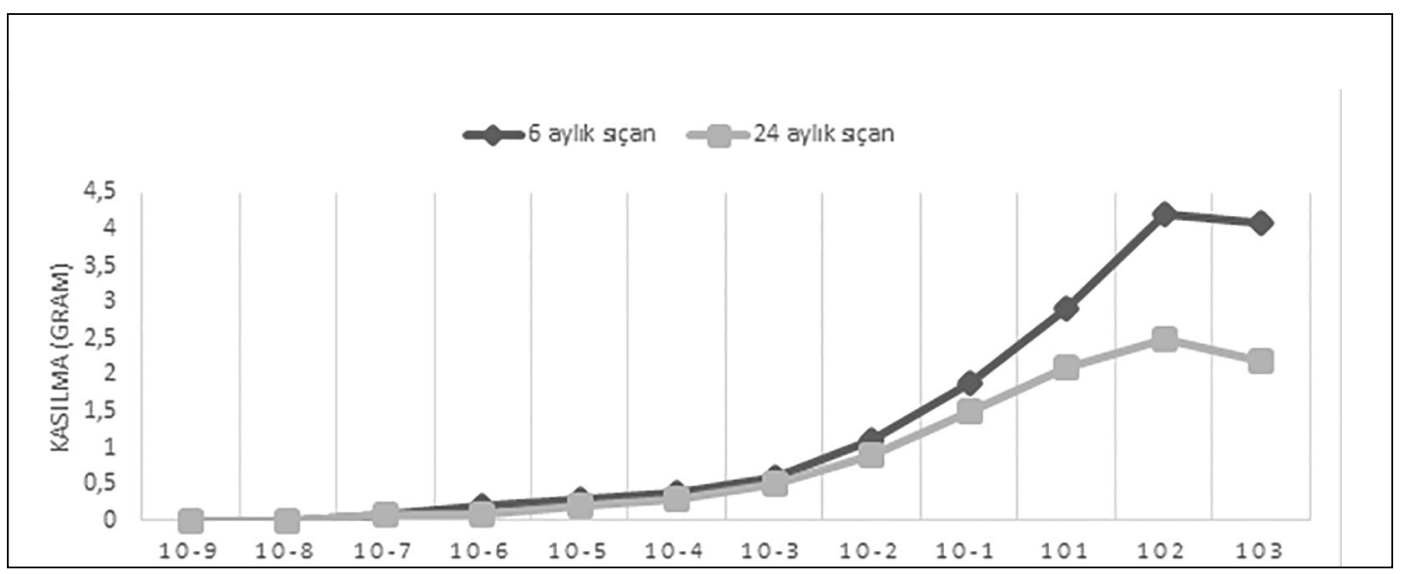

Şekil 1: Asetilkolin varlığında genç ve yaşlı sıçan mesane düz kasında oluşan kontraksiyonların karşılaştırılması

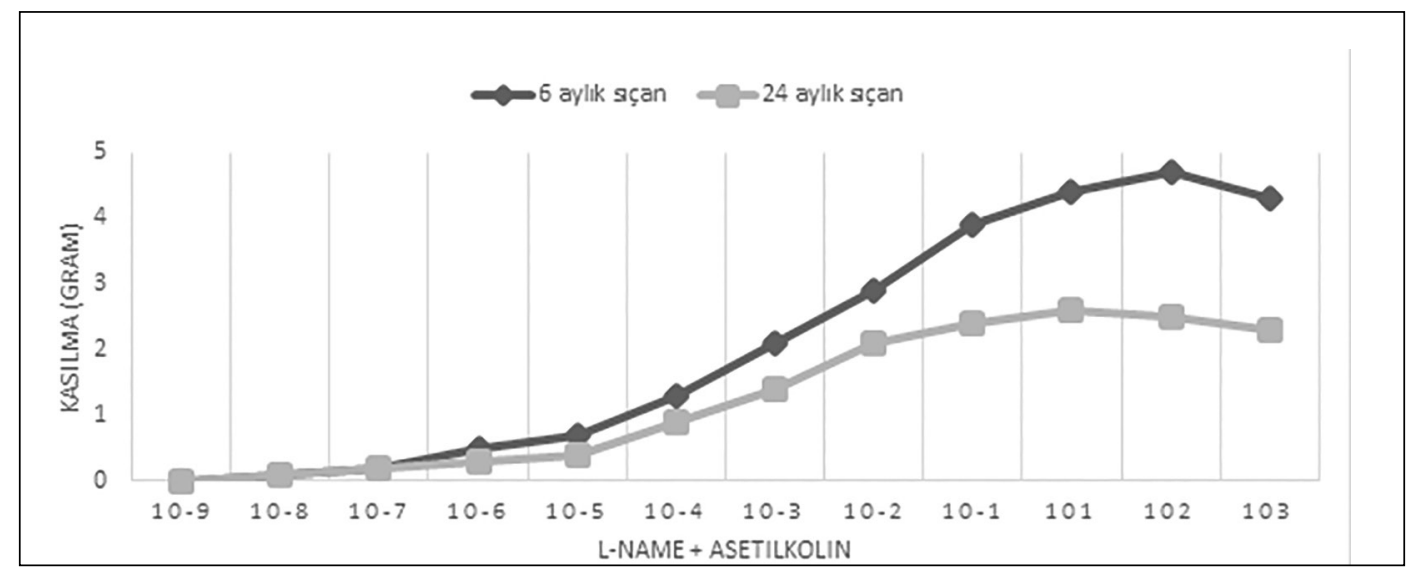

Şekil 2: L-NAME + Asetilkolin varlığında genç ve yaşlı sıçan mesane düz kasında oluşan kontraksiyonların karşılaştırılması 
$\mathrm{KCl}$ ile yapılan kontraksiyon çalışmalarında, artan konsantrayonlarda KCl'ye maruz birakılan genç ve yaşlı sıçan mesane dokularının verdiği kasılma yanıtları arasında düşük ve yüksek konsantrasyonlarda istatistiksel olarak anlamlı farklılık saptanmadı ( $\mathrm{p}>0.05$ ) (Şe- kil 3). 10-4 M L-NAME ile yarım saat preinkübasyon yapılan genç ve yaşlı sıçan mesane dokuları arasında, KCl’ye karşı alınan kasılma yanıtları arasında düşük ve yüksek konsantrasyonlarda istatistiksel olarak anlamlı farklılık saptanmadı ( $>>0.05)$ (Şekil 4).

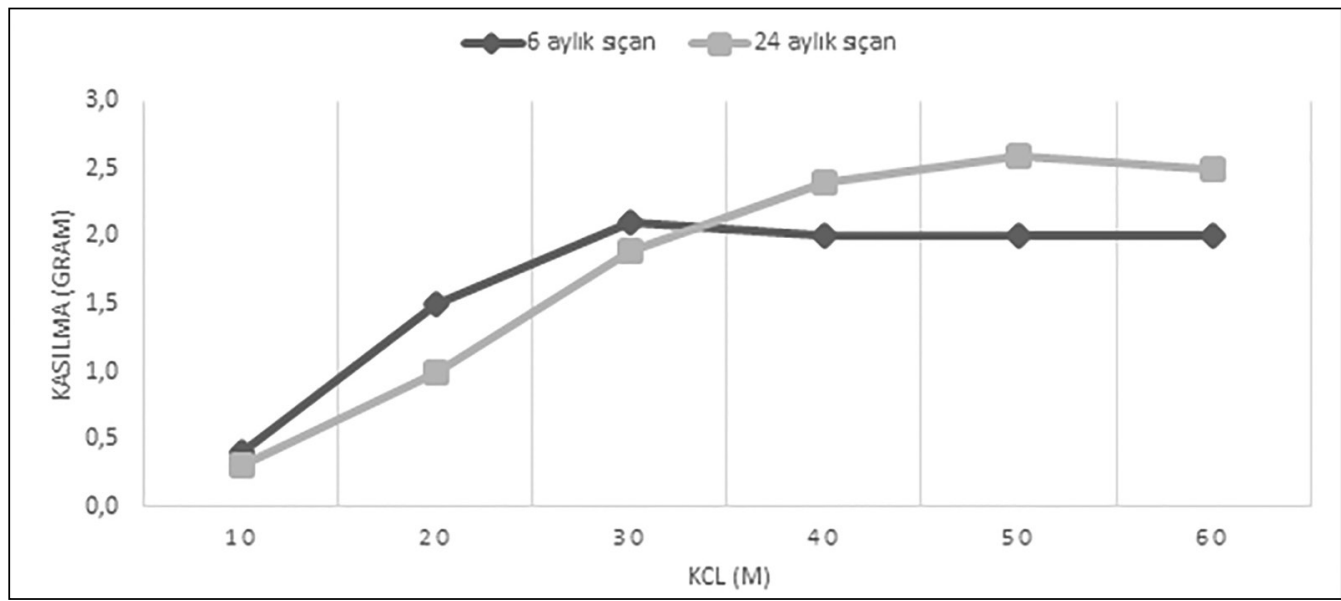

Şekil 3: $\mathrm{KCl}$ varlığında genç ve yaşlı sıçan mesane düz kasında oluşan kontraksiyonların karşılaştırılması

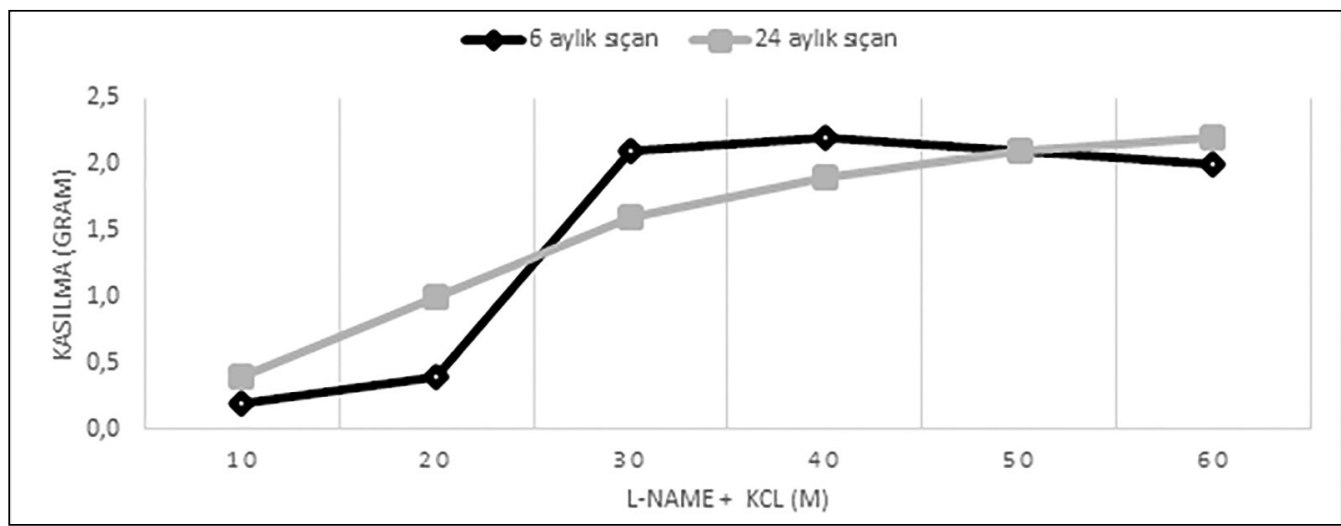

Şekil 4: LL-NAME + KCl varlığında genç ve yaşlı sıçan mesane düz kasında oluşan kontraksiyonları karşılaştırılması

\section{Gevşeme Çalışması}

10-4 M asetilkolin ile kasılmış genç ve yaşlı sıçan mesanelerinin sodyum nitroprusside verdikleri gevşeme yanıtları değerlendirildiğinde, 24 aylık yaşlı sıçan mesanelerinin düşük dozlarda istatistiksel olarak anlamlı gevşeme yanıtı verdiği görüldü ( $\mathrm{p}<0.05)$ (Şekil 5). 10-4 $M$ ve daha yüksek dozlarda ise iki grup arasında farkl1lık saptanmadı. 10-4 M asetilkolin ile kasılmış genç ve yaşlı sıçan mesanelerinin fenilefrine verdikleri gevşeme yanıtları değerlendirildiğinde, yine aynı şekilde 24 aylık yaşlı sıçan mesanelerinin düşük dozlarda istatistiksel olarak anlamlı gevşeme yanıtı verdiği görüldü $(\mathrm{p}<0.05)$ (Şekil 6). 10-4 M ve daha yüksek dozlarda ise iki grup arasında farklılık saptanmad1. 3x10-6 M konsantrasyonlara kadar $\mathrm{KCl}$ ile kontraksiyon oluşturulmuş 24 aylık sıçanların sodyum nitoprusside verdikleri gevşeme yanıtlarında, 6 aylıklara göre istatistiksel olarak anlamlı gevşeme yanıtı izlendi ( $\mathrm{p}<0.05)$ (Şekil 7). Daha yüksek dozlarda ise iki grup arasında farklılık saptanmadi. $\mathrm{KCl}$ ile kontraksiyon oluşturulmuş mesane dokularına, fenilefrine verilen gevşeme yanıtları incelendiğinde 10 8M’a kadar düşük dozlarda istatistiksel olarak anlamlı olmasa da yaşlı sıçanların mesanelerinde genç gruba göre daha yüksek gevşeme yanıtı izlendi. Daha yüksek dozlarda ise 24 aylık sıçanlarda istatistiksel olarak anlamlı gevşeme yanıtı tespit edildi $(\mathrm{p}<0.05)$ (Şekil 8). 


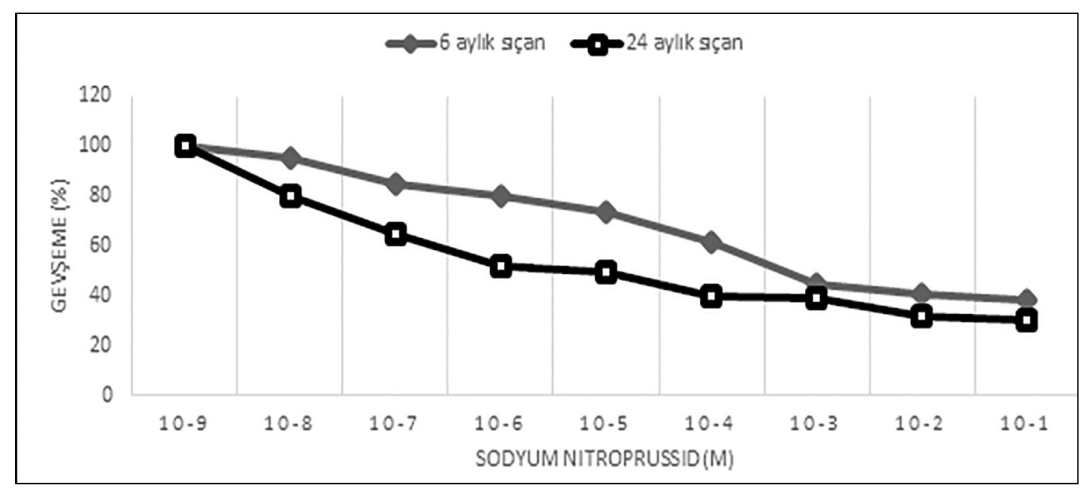

Şekil 5: 10-4M Asetilkolin ile kasılmış dokularda sodyum nitroprussid ile oluşan genç ve yaşlı sıçan mesane gevşeme yanıtlarının karşılaştırılması

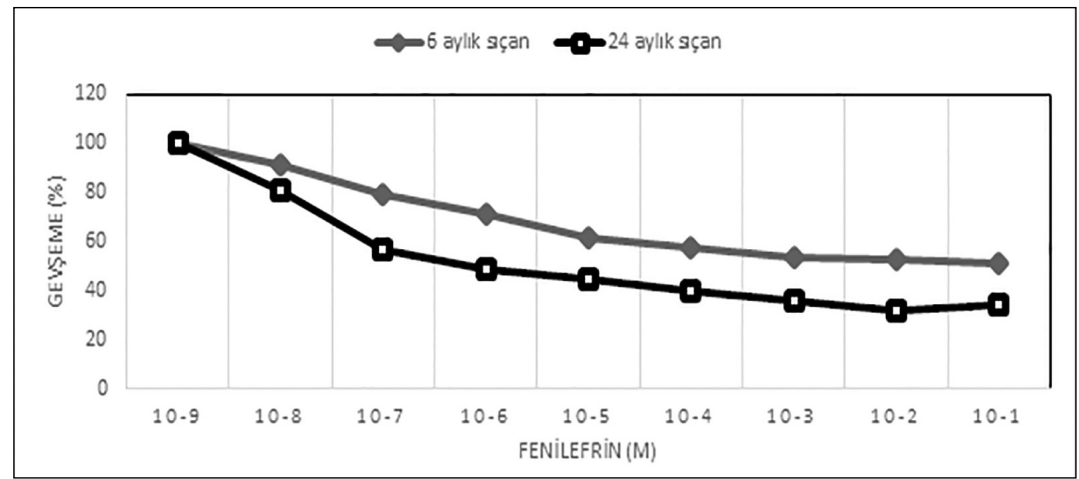

Şekil 6: $10^{-4} \mathrm{M}$ Asetilkolin ile kasılmış dokularda fenilefrin ile oluşan genç ve yaşlı sıçan mesane gevşeme yanıtlarının karşılaştırılması

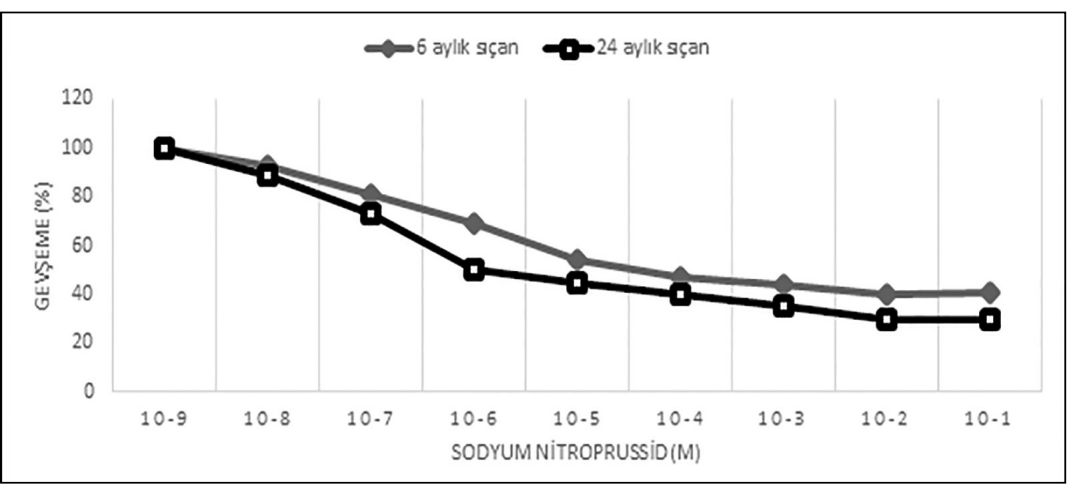

Şekil 7: 30 M KCL ile kasılmış dokularda sodyum nitroprussid ile oluşan genç ve yaşlı sıçan mesane gevşeme yanıtlarının karşılaştırılmasıı

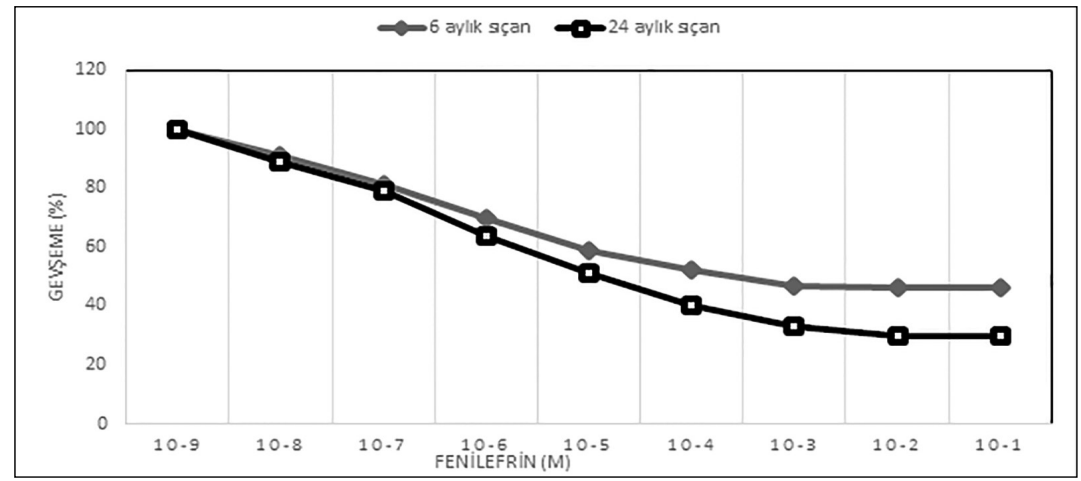

Şekil 8: 30 M KCL ile kasılmış dokularda sodyum fenilefrin ile oluşan genç ve yaşlı sıçan mesane gevşeme yanıtlarının karşılaştırılması 


\section{TARTIŞMA}

Alt üriner sistem fizyolojisi ve morfolojisinde yaşlanmanın önemli rol oynadığına dair görüşler gündemdedir. Ancak mesanede yaşa bağlı değişikliklerin ne zaman ve nasıl başladığı, ne derece önem taşıdığ hala net olarak açıklığa kavuşturulamamıştır ${ }^{17}$. Başlangıçta obstrüksiyon sorumlu tutulmuştur. Ancak obstrüksiyonu giderilen erkeklerin önemli bir kısmında AÜSS’nin devam etmesi ya da aynı yaş grubunda obstrüksiyonu olmayan kadın hastalarda da benzer yakınmaların görülmesi, patofizyolojide değişik bakış açılarını gündeme getirmiştir. Yakın zamanda yapılan bir çalışmada, semptomların obstrüksiyonla birlikte yaşlanmaya bağlı mesanede oluşan yapısal ve fonksiyonel değişiklikleri de içeren multipl mekanizmalarla oluştuğu belirtilmiştir ${ }^{18}$. Obstrüksiyona maruz kalmış mesanelerde yapılan çalışmalarda ortaya çıkan en erken morfolojik değişikliğin mesane ağırlığında artış ve duvarındaki kalınlaşmanın olduğu gösterilmiştir. $\mathrm{Bu}$ durumun mesanenin kasılma yeteneğinde belirgin bir azalmaya neden olduğu bildirilmiştir ${ }^{19,20}$. Yaşa bağlı olarak meydana gelen iki önemli mesane disfonksiyonu ise detrusör instabilitesi ve bozulmuş detrusör kontraktilitesidir ${ }^{21}$. Detrusör aşırı aktivitesi, yaşlanmaya bağlı üriner inkontinansın en sık sebebi kabul edilmekte olup, yaşlı popülasyonun \%40 ila 70’inde görülmektedir ${ }^{22}$.

Yaşlanma ile birlikte objektif olarak maksimum idrar akım hızında azalma, rezidüel idrar miktarında artma, işeme volümü ve mesane kapasitesinde azalma gibi ürodinamik değişiklikler hem erkek hem de kadınlarda görülmektedir ${ }^{23}$. Bu gibi gözlemler AÜSS’nın patofizyolojik temelinin cinsiyetten bağımsız olarak yaşlanma ile mesane sinirlerinde, vaskülaritesinde, ürotelyum ve düz kasında meydana gelen değişikliklere bağlı olabileceği görüşlerini desteklemektedir ${ }^{24}$. Pinggera ve arkadaşları AÜSS’leri olan yaşlı hastaların mesanelerini asemptomatik genç hasta mesaneleri ile karşılaştırdıklarında, yaşlı hasta mesanelerinde kan akışını anlamlı derecede azalmış olarak tespit etmişler$\operatorname{dir}^{25}$. Yine Saito ve arkadaşları yaptıkları bir çalışmada internal iliak arter ligasyonu ile iskemi oluşturdukları mesanede kontraktil yanıtın azaldığını göstermişler$\mathrm{dir}^{26}$. Yaşla birlikte üriner sistem düz kasının reseptör karakteristiklerinde değişiklikler olduğu ve çeşitli farmokolojik ajanlara verilen yanıtta farklilıklar olduğu gösterilmiştir ${ }^{27}$. Fizyolojik olarak detrüsör kontraksiyonu nörohumoral stimülasyonla düz kas hücrelerindeki muskarinik reseptörlerin asetilkolin ile etkileşmesi sonucu gerçekleşir ${ }^{28}$. Mesane kontraksiyonlarının bir kısmının atropine dirençli olması, kontraksiyonlarda sinir stimülasyonunun direkt rol oynayabileceğini düşündürmüştür. Bununla birlikte atropine dirençli kontraksiyonların etki mekanizması tam olarak açıklanamamıştır. Adenosinetriphosphate (ATP), vazointestinalpeptid (VIP), prostaglandinler (PG) gibi NANC mekanizmalarla ilgili olabileceği bildirilmiştir ${ }^{29}$. Bunlar arasında purinerjik reseptörler yoluyla kasılmaya yol açan, parasempatik NANC nörotransmitter olarak ATP daha olası gözükmektedir ${ }^{30}$. Yine alt üriner sistemde NOS enzimi gösterilmiş ve NANC reseptörlerde nitrik oksit nörotransmitter olarak izlenmiştir. Dolayısıyla nitrik oksit pek çok düz kasta olduğu gibi, alt üriner sistemde de gevşetici rol oynayabilir. Andersonn ve arkadaşları NOS eksikliği olan sıçanların mesane düz kaslarında hipertofi geliştiğini ve detrüsör gevşemesinde azalma olduğunu göstermişlerdir15. Yine Ozawa ve arkadaşları irritasyona bağlı mesane instabilitesinin NO ile baskılanabileceğini göstermişlerdir ${ }^{31}$.

Daha önce yapılan çalışmalarda yaşlı sıçan mesanelerinde asetilkoline alınan kontraksiyon yanıtı araştırılmakla birlikte, asetilkolinle eş zamanlı NOS inhibitörü olan L-NAME'in verildiği çalışmaya rastlanılmamıştır. $\mathrm{Bu}$ çalışmada ise L-NAME verilerek ortamdaki nitrik oksit azaltıldığında, yüksek konsantrasyonlarda olmak üzere genç sıçanlarda anlamlı kontraksiyon yanıtı izlendi. Yine gerek asetilkolin gerekse KCL ile kontraksiyon oluşturulmuş genç ve yaşlı sıçan mesane düz kasları NO donörü olan sodyum nitroprussid ile muamele edildiğinde, düşük dozlarda olmakla birlikte yaşlı sıçanların anlamlı derecede gevşeme yanıtı verdiği görüldü. Bu durum yaşlanma ile birlikte hala net olarak mekanizması açıklığa kavuşturulamamış olan NANC mekanizmaların rolünü ortaya koyması açısından önemli olabilir. Yoshida ve arkadaşları yaşla birlikte purinerjik reseptörlerde artma, kolinerjik reseptörlerdeise azalma olduğunu, atropine dirençli kontraksiyonlarda ise artış olduğunu göstermişlerdir ${ }^{32}$. Bizim çalışma- 
mızda da yüksek dozlarda olmakla birlikte genç sıçanların asetilkoline kontraksiyon yanıtında istatistiksel olarak anlamlı artış izlenmesi, kolinerjik reseptörlerde yaşlanma ile azalma olduğu görüşünü desteklemektedir. Saito ve arkadaşları ise $\alpha$-adrenerjik uyarılara karşı yaşlılarda artmış detrüsör yanıtı tespit etmişlerdir ${ }^{33}$. $\alpha$-adrenerjik uyarılara artmış yanıt ve $\beta$ - adrenerjik inhibitörlere azalmış yanıt alınması, norepinefrinin yaşlı mesanelerde genç mesanelerin aksine gevşeme yerine kasılmaya yol açabileceği bildirilmiştir ${ }^{34}$. Bu durum yaşlilıkta idrar depolama fonksiyonunda bozulmaya ve inkontinans gelişmesine yol açabilir. Bu çalışmada $\alpha$-adrenerjik agonist olan fenilefrine asetilkolinle oluşturulan kontraksiyonlarda düşük dozlarda, $\mathrm{KCl}$ ile kontraksiyonlarda ise yüksek dozlarda yaşlı sıçanların mesanelerinde gevşeme yanıtı alınmıştır. Bu da yaşla birlikte adrenerjik reseptör karekteristiklerinin değiştiğini göstermektedir. Kamei ve arkadaşları erkek ve dişi farelerde yakın zamanda yaptıkları bir çalışmada, yaşı erkeklerde M3 reseptörlerinin, yaşlı dişilerde ise beta 2 -adrenoseptörlerin ekspresyonunun azaldığını ve her iki cinsiyette yaşlanma ile muskarinik stimülasyona daha düşük tepkiler görüldüğünü ortaya koymuşlar$\mathrm{d}^{35}{ }^{35}$. KCl ve L-NAME varlığında KCl'ye genç ve yaşlı sıçan detrüsörünün verdiği kontraksiyon yanıtları değerlendirildiğinde, iki grup arasında anlamlı farklılık izlenmedi. Bu konuda detrüsör aşırı aktivitesinin tedavisinde kullanılabilecek potasyum kanal açıcılarını da kapsayan daha ileri çalışmalara ihtiyaç vardır. Sonuç olarak asetilkolinle oluşturulan kontraksiyonlarda fenilefrine düşük dozlarda, $\mathrm{KCl}$ ile olan kontraksiyonlar da ise yüksek dozlarda, yaşlı sıçanların mesanelerinde gevşeme yanıtı alınması yaşla birlikte adrenerjik reseptör karakteristiklerinin değiştiğini göstermektedir. Yüksek dozlarda olmakla birlikte genç sıçanların asetilkoline kontraksiyon yanıtında istatistiksel olarak anlamlı artış izlenmesi, kolinerjik reseptörlerde yaşlanma ile azalma olduğu görüşünü desteklemektedir. Yine yaşlı sıçanlarda nitrik oksitle gevşeme yanıtlarında anlamlı farklılık saptanması, henüz mekanizması tam anlaşılamamış olan NANC mekanizmaların işeme disfonksiyonunda rol oynayabileceğini göstermektedir.

\section{SONUÇ}

Çalışmamızda yaşlı ve genç sıçan mesanelerinin aynı farmakolojik ajanlara karşı verdiği yanıtlarda farklılık olduğu gözlemlenmiştir. Buna paralel olarak yaşlanma ile birlikte reseptör karakteristiklerinde meydana gelen değişiklikler sonucu mesane fonksiyonlarında önemli farklılıklar oluşması söz konusu olabilir. Bu gözlem ileri yaş grubunda sık olarak görülen AÜSS’nin patafizyolojisinde yaşlanmanın da önemli bir rol oynadığını göstermektedir. Hayat kalitesini oldukça düşüren işeme disfonksiyonunun patofizyolojisini aydınlatacak detaylı klinik ve deneysel çalışmalara ihtiyaç olduğu açıktır.

\section{KAYNAKLAR}

1. Garrawy WM, Collins GN, Lee RJ. High prevalence of benign prostatic hypertrophy in the community. Lancet 1991; 338: 469-71.

2. Chapple CR. The total approach in lower urinary tract symptoms. Benign prostatic hyperplasia (LUTS-BPH) management: Introduction and conclusion. Euro Urol 2003; 2 (spp):1-5.

3. Lee AS, Garrawy WM, Simpson RJ, Fisher W, King D. The natürel history of untreated lower urinary tracts ymptom in middle age and elderly men over a period of five years. Euro Urol 1998;34:325-32.

4. Poulsen AL, Schou J, Puggaard L, Torp - Pedersen S, Nordling J. Prostatic enlargement, semptomatology and pressure flow evaluation: interrelations in patients with symptomatic BPH. Scand J Urol Nephrol 1994;157:67-74.

5. Holtgrewe HL. Transurethral prostatectomy. Urol Clin North Am 1995;22: 357-63.

6. Madersbacher S, Phyca A, Schatzi G et al. The aging lower urinary tract: a comparative urodynamic study of men and women. Urology 1998;51:206-11.

7. Cellek S, Cameron NE, Cotter MA, Fry CH, Ilo D. Microvascular dysfunction and efficacy of PDE5 inhibitors in BPH-LUTS. Nat Rev Urol 2014;11:231-41.

8. Chancoller MB, Yoshimura N. Physiology and pharmacology of the bladder and urethra. Campbell'sUrology (Walsh PC, Retik AB, Vaughan ED, Wein AJ). Eightedition. Phiadelphia, Saunders 2002;2:831-86.

9. Kondo S, Morita T, Tashima Y. Muscarinic cholinergic receptor subtypes in human detrusor muscle studied by labeled and nonlabeled prenzepine, AFDX-116 and DAMP. Urol Int 1995;54:150-158. 
10. Harris DR, Marsh KA, Birmingham AT. Expression of muscarinic M3 receptors coupled to inositol phospholipid hidrolisis in human detrusor muscle cells. J Urol. 1995; 154:150-158.

11. Park YC, Tomiyama Y, Hayakawa K, Akahane M, Ajisawa Y, Miyatke R. Existence of a $\beta 3$ adreno receptor and it functional role in the human ureter. J Urol 2000;164: 1364-70.

12. Lepor H, Gup D, Shapiro E, Baumann M. Muscarinic cholinergic receptors in the normal and neurogenic humanbladder. J Urol 1989;142:869-74.

13. McGurray G, Dass N, Ho KMT, Brading AF. Purinergicm echanisms in primate urinary bladder. Br J Urol 1997;80:182-88.

14. Canda A.E, Cross C.R, Chapple C.R. Pharmacology of the Lower Urinary Tract and Management of Overactive Bladder. J Turkish-GermanGynecolAssoc 2006:7;146-57.

15. Anderson KE, Persson K. Nitricoxide synthase and the lower urinary tract: Possible implications for physiology and pathophysiology. Scand J Urol Nephrol 1995;175: 4551.

16. Hennenberg M, Stief CG, Gratzke C. Pharmacology of the lower urinary tract. Indian J Urol 2014;30:181-188.

17. Remzi D, Tekgül S. Alt üriner sistemin yaşlanma ve infravezikal obstrüksiyona cevabı. Özen HA(edt): Benign prostat hiperplazisi. Hekimler yayın birliği, Ankara 1996;49-51.

18. Andersson KE, Boedtkjer DB, Forman A. The link between vascular dysfunction, bladder ischemia, and aging bladder dysfunction. TherAdv Urol 2017;9:11-27.

19. Lewin R, Malkowicz B, Wein AJ. Recovery from short term obstruction of the rabbit urinary bladder. J Urol 1985;134:134-9.

20. Mostin JL, Karim OM, Koeveringe V. Theguinapig as a model of gradual urethral obstruction. J Urol 1991;148:8549.

21. Wein AJ. Assessing treatment result in benign prostatic hiperplasia. Urol Clin North Am 1995;22:345-50.

22. Couillard DR, Webster GD. Detrusorinstability. Urol Clin North Am 1995;22:593-98.

23. Artibani W. Diagnosis and significance of idiopathic overactive bladder. Urology 1997;50:25-31.

24. Azadzoi KM, Tarcan T, Kozlowsky R, Krani JR, Siroky MB.
Over activity and structural changes in the chronically ischemic bladder. J Urol 1999;162:1768-78.

25. Pinggera G, Mitterberger M, Pallwein L et al. Alpha-Blockers improve chronic ischaemia of the lower urinary tract in patients with lower urinary tract symptoms. BJU Int 2008;101:319-324.

26. Saito M, Ohmura M, Kndo A. Effects of aging on blood flow to the bladder and bladder function. Urol Int1999;62:9398 .

27. Nishimoto $T$, Latifpour J, Wheeler MA, Yoshida $M$, Weiss RM. Aged dependent alterations in $\beta$ adrenergic responsiveness of rat detrusor smooth muscle. J Urol 1995; 153:1701-05.

28. Steers WD. Physiology and phamocology of the bladder and urethra. Campbell'sUrology (Walsh PC, Retik AB, Vaughan ED, Wein AJ). Seven edition. Saunderscompany, Phiadelphia 1997;870-915.

29. Zar MA, Irawani MM, Luheshi GN. Effect of nifedepine on the concractile responses of the isolated rat bladder. J Urol 1990;143:835-39.

30. Luheshi GN, Zar MA. Purinoceptor desensitization impairs but dose not abolish the noncholinergic motor transmission in rat isolated urinary bladder. Eur J Pharmacol 1990;185:203-08.

31. Ozawa H, Chancellor MB, Jung SY. Effect of intra vesical nitricoxide therapy on cyclophosphamide induced cytitis. J Urol 1999;162:2211-16.

32. Yoshida M, Homma Y, Inadome A et al. Age related changes in cholinergic and purinergic neurotransmission in human izolated bladder smooth muscle. Exp Gerontology 2001;36:99-109.

33. Saito M, Kondo A, Gotoh M. Age related changes in the response of the rat urinary bladder to neurotransmitters. NeurourolUrodyn 1993;12:191-197.

34. Lin ATL, Yang CH, Chang LS, Chen MT. Age related changes on the adrenergic contractile response in the urinary bladder and the prostate. Neurourol Urodyn 1992;11:304-9.

35. Kamei J, Ito $\mathrm{H}$, Aizawa $\mathrm{N}$ et al. Age-related changes in function and gene expression of the male and female Mouse bladder. Sci Rep 2018;8:2089-98. 